\title{
A facile synthetic route to benzimidazolium salts bearing bulky aromatic $\mathrm{N}$-substituents
}

\author{
Gabriele Grieco, Olivier Blacque and Heinz Berke*
}

\author{
Full Research Paper \\ Address: \\ Department of Chemistry, University of Zurich, Winterthurerstrasse \\ 190, CH-8057 Zurich, Switzerland, Fax: (+41)-1-635-6802

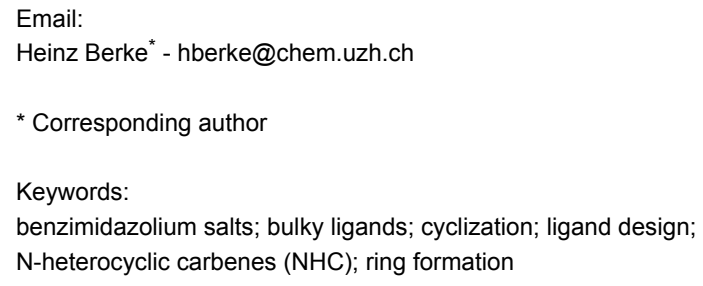

Beilstein J. Org. Chem. 2015, 11, 1656-1666. doi:10.3762/bjoc. 11.182

Received: 13 July 2015

Accepted: 01 September 2015

Published: 17 September 2015

Associate Editor: T. P. Yoon

(C) 2015 Grieco et al; licensee Beilstein-Institut. License and terms: see end of document.

\begin{abstract}
An atom-economic synthetic route to benzimidazolium salts is presented. The annulated polycyclic systems: 1,3-bis(2,4,6trimethylphenyl)-1H-benzo[ $d]$ imidazol-3-ium chloride (1-Cl), 1,3-bis(2,6-diisopropylphenyl)-1H-benzo[d]imidazol-3-ium chloride (2-Cl), 1,3-diphenyl-1H-benzo[ $d$ ] imidazol-3-ium chloride (3-Cl), and 1,3-di(pyridin-2-yl)-1H-benzo[ $d]$ imidazol-3-ium chloride (4-Cl) were prepared in a two-step synthesis avoiding chromatographic work-up. In the key step triethyl orthoformate is reacted with the corresponding $N^{1}, N^{2}$-diarylbenzene-1,2-diamines and then further transformed in situ, by alkoxy abstraction using trimethylsilyl chloride (TMSCl), and concomitant imidazole ring closure.
\end{abstract}

\section{Introduction}

Imidazole-based N-heterocyclic carbenes (NHCs) are stable systems serving as ancillary ligands mainly to construct organometallic complexes. These NHCs are sterically and electronically tunable, strongly binding ligand units in complexes in the search for new materials [1-5] and for catalysts of homogeneous catalysis [6-10]. Besides that NHCs have great potential in organocatalysis [11-15], their electronic properties, $\sigma$-donor ability and $\pi$-back donation can be tuned and, based on these properties, they possess great electronic flexibility. These ligands or catalysts reached a prominent position in the mentioned fields of chemistry. It is noteworthy that on the ma- terial's side NHC-type carbene-borane adducts and metal complexes of them can also be used as electroluminescent materials (OLEDs) [16-19].

After the discovery of NHCs in 1968 by Wanzlick and Öfele, who isolated stable diamino-substituted carbenes, around 20 years later Arduengo further stabilized these potential ligand groups by embedding them into imidazole rings and increased in addition the steric congestion [20]. It is important to recognize that synthetically the stable forms for handling of imidazole carbenes are imidazolium salts. In imidazolium-based 
NHC chemistry two synthetic aspects are important: 1) there are several fundamental synthetic routes available that allowed substitution in the 4 and 5 positions of the imidazole ring; and 2 ) the routes available can be carried out as one-pot reactions $[21,22]$ or two-step preparations [23,24].

Annulated polycyclic NHCs can, however, not always be prepared in straightforward ways, especially when the compounds are designed to bear bulky aromatic moieties as $\mathrm{N}^{1}, \mathrm{~N}^{2}$ substituents. As mentioned before the synthetic pre-stages of NHCs are always imidazolium salts, but benzimidazolium salts, which possess two aromatic $\mathrm{N}^{1}, \mathrm{~N}^{2}$-substituents are rare. More common are benzimidazolium salts having different $\mathrm{N}^{1}, \mathrm{~N}^{2}$ substituents, where one of the $\mathrm{N}$-substituent is an aromatic or a benzylic group and the other substituent an alkyl [25-30] or benzyl [31,32] group. A synthetic strategy for the preparation of sterically demanding monoaryl benzimidazolium salts starts from the corresponding benzimidazoles possessing a bulky aryl group introducing the other bulky N-substituent by means of an $\mathrm{N}$-alkylation [33-37]. Indeed benzimidazolium salts that bear $\mathrm{N}$-alkyl or N-alkenyl substituents can be accessed synthetically by simple routes in comparison with those possessing two $\mathrm{N}$-aromatic substituents.

We therefore sought the preparation of sterically demanding $N^{1}, N^{2}$-benzimidazolium systems as, for instance, those accessed by Chianese and co-workers [38]. But for the access to other aryl-substituted benzimidazolium species we had to face complex synthetic pathways, for which we intended to simplify these as much as possible.

In addition to the 1,3-benzoimidazolium salts prepared by Chianese and co-workers, polycyclic diaminocarbenes were reported possessing mesityl substituents in the $\mathrm{N}^{1}, \mathrm{~N}^{2}$-positions and in addition benzoquinone $[39,40]$ or quinone [41] imida- zole annulated systems or those with an annulated 1,3-dimesitylbenzene ring (1-Cl) [42,43] (Figure 1). The synthetic routes are very sensitive to the respective substitution patterns, for instance, the procedure for $1-\mathrm{Cl}$ failed to access the analogous 1,3-(2,6-diisopropyl)benzimidazolium salt 2-Cl.

In this article we describe a two-step synthesis for the sterically hindered benzimidazolium salts: 1,3-bis(2,4,6-trimethylphenyl)$1 H$-benzo $[d]$ imidazol-3-ium chloride (1-Cl) $[42,43]$, 1,3bis(2,6-diisopropylphenyl)- $1 H$-benzo[d]imidazol-3-ium chloride (2-Cl), 1,3-diphenyl-1H-benzo[d]imidazol-3-ium chloride (3-Cl) [44,45] and 1,3-di(pyridin-2-yl)- $1 H$ benzo[ $d]$ imidazol-3-ium chloride (4-Cl) [45] (Figure 2). The synthesis starts from suitable aryl diamines applying the combination of the reagents trimethylsilyl chloride and triethyl orthoformate as $\mathrm{C}_{1}$ component to accomplish concomitantly cyclization to the imidazole rings. We expected high yields and reduced overall reaction times when compared with the previously reported synthetic pathways.

Excluding the strongly sterically encumbered benzimidazolium salt 2-Cl, the benzannulated $\mathrm{NHCs} \mathbf{1}-\mathrm{Cl}, 3-\mathrm{Cl}$ and $4-\mathrm{Cl}$ were prepared earlier, however, 1-Cl was prepared by a relatively complex reaction scheme. Moreover, the benzimidazolium salts 1-Cl to 4-Cl possessing a variety of $\mathrm{N}^{1}, \mathrm{~N}^{2}$-substituents were designed to eventually allow facile release of the benzoimidazole carbenes acting eventually as ligands in complexes by deprotonation avoiding additional complications that could arise from the anions of the benzimidazolium salts.

\section{Results and Discussion}

The starting point for the syntheses of the benzannulated NHCs 1-Cl, 2-Cl and 3-Cl was the development of a straightforward palladium-catalyzed preparation of the known $N^{1}, N^{2}$-diphenylbenzene-1,2-diamine compounds 5, 6 and $\mathbf{7}$ in dependence on<smiles>Cn1c2c(n(C)c1=O)C(=O)c1ccccc1C2=O</smiles>

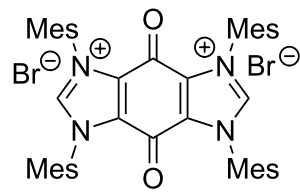

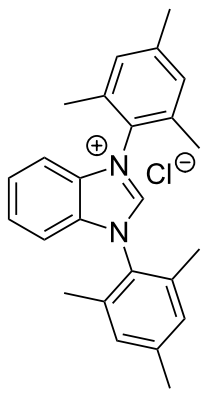

$1-\mathrm{Cl}$

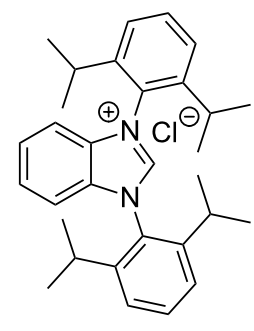

2-Cl 


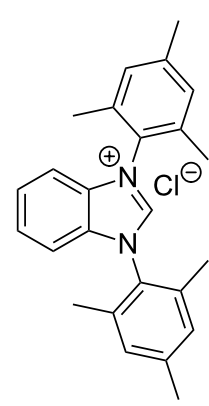

$1-\mathrm{Cl}$

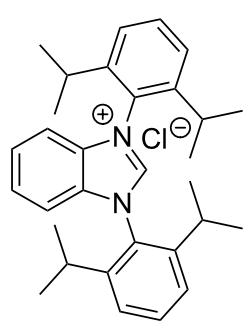

2-Cl

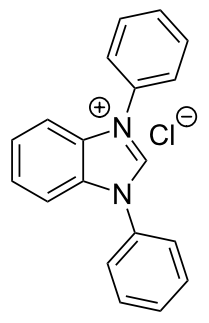

3-Cl<smiles>Cl[n+]1cn(-c2ccccn2)c2ccccc21</smiles>

4-Cl

Figure 2: Benzannulated NHCs of this work. Benzannulated imidazolium chloride salts 1-Cl, 2- $\mathrm{Cl}, 3-\mathrm{Cl}$ and $4-\mathrm{Cl}$ of various steric demands and ligating properties in complexes.

an earlier synthetic route [46] (Scheme 1). In the case of compound 5 a better yield ( $89 \%$ ) could be accomplished when the reaction was carried out at $92{ }^{\circ} \mathrm{C}$ instead of $120^{\circ} \mathrm{C}$ as reported [47].

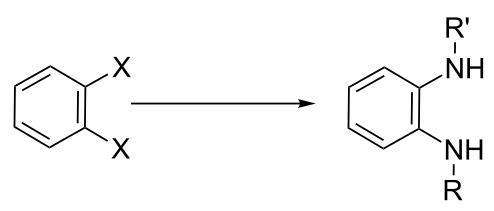

$5 \mathrm{R}, \mathrm{R}^{\prime}=\mathrm{Ph} ; \mathrm{X}=\mathrm{Cl}$; yield $89 \%$; (i)

$6 \mathrm{R}=$ Mes; $\mathrm{R}^{\prime}=$ Mes; $\mathrm{X}=\mathrm{Cl} ;$ yield $82 \%$ (ii)

$7 \mathrm{R}=(2,6-\mathrm{iPr}) \mathrm{C}_{6} \mathrm{H}_{4} ; \mathrm{R}^{\prime}=(2,6-\mathrm{iPr}) \mathrm{C}_{6} \mathrm{H}_{4} ; \mathrm{X}=\mathrm{Br} ;$ yield $58 \%$ (ii)

$8 \mathrm{R}, \mathrm{R}^{\prime}=\mathrm{Py} ; \mathrm{X}=\mathrm{NH}_{2} ;$ yield $91 \%$ (iii)

Scheme 1: Synthesis of the $N^{1}, N^{2}$-diaryl-1,2-benzenediamines 5, 6, 7 and 8. i) $\mathrm{Pd}(\mathrm{dba})_{2}, \mathrm{P}(t-\mathrm{Bu})_{3}, t-\mathrm{BuONa}$, toluene, $92{ }^{\circ} \mathrm{C}$. ii) $\mathrm{Pd}(\mathrm{dba})_{2}$, $\mathrm{P}(t-\mathrm{Bu})_{3}, t$-BuONa, toluene, $115^{\circ} \mathrm{C}$. iii) $\mathrm{S}_{\mathrm{N}} A r$ reaction: 2-chloropyridine neat, $185^{\circ} \mathrm{C}$, microwave.

Somewhat modified approaches were used for the syntheses of the $N^{1}, N^{2}$-diarylbenzene-1,2-diamines $\mathbf{6}$ and 7 compared with the preparation of the $N^{1}, N^{2}$-di(pyridine-2-yl)benzen-1,2-diamine (8). The Buchwald-Hartwig amination was applied in the syntheses of $\mathbf{5}$ and $\mathbf{6}$ where 1,2-dichlorobenzene was coupled with aniline and 2,4,6-trimethylaniline, respectively (Scheme 1). Attempting the synthesis of the $N^{1}, N^{2}$-bis(2,6diisopropylphenyl)benzene-1,2-diamine (7) and using 1,2dichlorobenzene as the starting compound, the mono-substituted product was obtained. To avoid this complication 1,2dibromobenzene had to be applied to eventually approach the preparation of $\mathbf{7}$. For 8 a reported synthetic procedure was used $[48,49]$ consisting of nucleophilic aromatic substitutions $\left(\mathrm{S}_{\mathrm{N}} \mathrm{Ar}\right)$ of benzene-1,2-diamine at 2-chloropyridine (Scheme 1). Once all the different $N^{1}, N^{2}$-diarylbenzene-1,2-diamines were prepared a method had to be developed to build up the imida- zolium salts by ring closure. 3-Cl and 4- $\mathrm{Cl}$ could principally be obtained from the corresponding $N^{1}, N^{2}$-diarylbenzene-1,2-diamines via two different cyclization pathways leading to the benzimidazolium salts 3-Cl [44] and 4- $\mathrm{BF}_{4}$ [48] (Scheme 2). But we also planned to access the chloride compounds 1- $\mathrm{Cl}$, 3-Cl and 4-Cl reported previously as tetrafluoroborate [48] and chloride [45] salts for two reasons: we wished to find a faster way to access them and it seemed advantageous to aim preferentially at the synthesis of benzimidazolium chlorides than at $\left[\mathrm{BF}_{4}\right]^{-}$salts, since in case the carbene will be generated in "in situ" reactions in the presence of metal complexes, the lower stability of the $\left[\mathrm{BF}_{4}\right]^{-}$anion could lead to complications generating side-products [50-52]. The preparations of both 3-Cl and 4-Cl started along the given lines with the syntheses of the respective aryl-substituted diamines, which had to undergo ring closure in the presence of a $\mathrm{C}_{1}$ component. For 3-Cl and 4-Cl the synthetic procedures proceed without noticeable problems, while complications were faced in the synthesis for 1-Cl and 2-Cl, particularly during the benzimidazole ring closures. Excluding the procedure of Borguet $[42,43]$ all the known procedures to accomplish imidazole ring formation $[44,45,48,53,54]$ of either 6 and 7 failed.

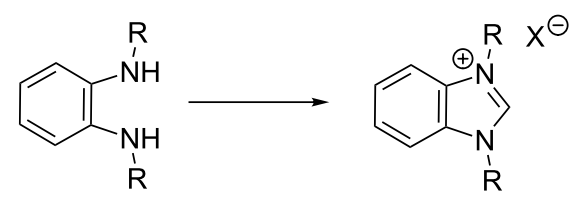

3-Cl: $\mathrm{R}=\mathrm{Ph} ; \mathrm{X}=\mathrm{Cl}^{-} ;$Yield $88 \% \quad$ (i)

4-BF $4: \mathrm{R}=\mathrm{Py} ; \mathrm{X}=\mathrm{BF}_{4}^{-} ;$Yield $99.7 \%$ (ii)

Scheme 2: Previous synthesis of the benzannulated $\mathrm{NHCs} \mathrm{3-Cl} \mathrm{and}$ $4-\mathrm{BF}_{4}$. Ring closure. i) $(\mathrm{EtO})_{3} \mathrm{CH}, \mathrm{HCl}$ (conc.), $\mathrm{HCOOH}, 80^{\circ} \mathrm{C}$ [44] ii) Microwave assisted synthesis: $\mathrm{NH}_{4} \mathrm{BF}_{4},(\mathrm{EtO})_{3} \mathrm{CH}, 160^{\circ} \mathrm{C}$ [47].

For instance, the method of Hintermann [23] that uses the combination of paraformaldehyde and trimethylsilyl chloride 
(TMSCl) gave satisfying results in the preparation of the known IMes and IPr derivatives, but failed for the synthesis of both 1-Cl and 2-Cl. In fact there are examples of $N^{1}, N^{2}$ bisarylethandiamines, which could be cyclisized to benzimidazolium salts in the presence of air, paraformaldehyde and hydrochloric acid [55], and the success of this synthetic approach was presumably crucially depending on the mode of action of $\mathrm{O}_{2}$ oxidizing the aminal intermediate. The failures to access 1-Cl and 2-Cl may originate from the high steric hindrance of the 2,6-substituents of the $N^{1}, N^{2}$-diarylbenzene1,2-diamines preventing initial aminal formation. Involving instead triethyl orthoformate has the advantage that this $C_{1}$ building block provides the right oxidation state for the cyclization process making the involvement of an oxidizing agent unnecessary [23] and, moreover, it possesses high electrophilicity required for this reaction. The method of Chianese et al. [38] demonstrated that the cyclization of $N^{1}, N^{2}$-diarylbenzene-1,2-diamine can be achieved with bulky substituents in the 3-, 4- and 5-positions of the $N^{1}, N^{2}$-phenyl rings, but this study clearly showed also that cyclization of the diarylbenzene diamines get difficult when bulkier groups are in 2- and 6-position of the $N^{1}, N^{2}$-substituents.

A reaction course is proposed for the ring closure of $5,6,7$ and 8 forming the benzimidazolium salts $\mathbf{1}-\mathrm{Cl}, \mathbf{2}-\mathrm{Cl}, \mathbf{3}-\mathrm{Cl}$ and $\mathbf{4}-\mathrm{Cl}$, which is suggested to pass through stages $\mathbf{a}$ and $\mathbf{b}$ with alcohol elimination (Scheme 3) and eventually then cyclization is initiated via the 2-ethoxy-1,3-diaryldihydrobenzimidazole species $\mathbf{c}$ and $\mathbf{d}$ enforced by the applied higher temperatures. TMSCl is assumed to abstract an alkoxide group and to deliver at the same time the chloride as the preferred counterion for the imidazolium salts.

As said, temperature plays a decisive role in the formation of stage d, requiring the $N, N$ '-diarylbenzene-1,2-diamines to be heated in triethyl orthoformate at almost reflux temperature $\left(145^{\circ} \mathrm{C}\right.$ ) for reaction times between 10 and $20 \mathrm{~min}$. Then TMSCl was added in large excess all at once leading to precipitation of greyish products, which indicated the formation of the benzimidazolium chlorides. In this way not only the known compound 1- $\mathrm{Cl}$ could be accessed in a short total reaction sequence ( 2 steps, one isolated intermediate product) instead of the 4 steps of the synthetic route reported earlier $[42,43]$ (Table 1). The application of new reagents avoided at the same time tedious column chromatography. Even the more sterically encumbered and elusive compound 2-Cl could obtained in this way (X-ray diffraction structure displayed in Figure 3). The yields of 1-Cl and 2-Cl were $68 \%$ and $28 \%$, respectively.

The previous synthesis of 1-Cl by Borguet and co-workers [42] required 4 steps. All the other earlier preparations and the preparation of this paper shown in Table 1 were accomplished in two steps. The overall reaction time required for the earlier synthetic access of 1-Cl was quite high (112 h), as well, in comparison with the use of the TMSCl-triethyl orthoformate reagent presented in this work. By this the total reaction time could be shortened to $17 \mathrm{~h}$ and the overall yields raised from $23 \%$ to $55 \%$. Despite the fact that 2 -step syntheses are<smiles>[R]Nc1ccccc1N([R])CC[C@H](OCC)C(C)(OCC)OCC</smiles>

(e) EtO'

(d)

(c)

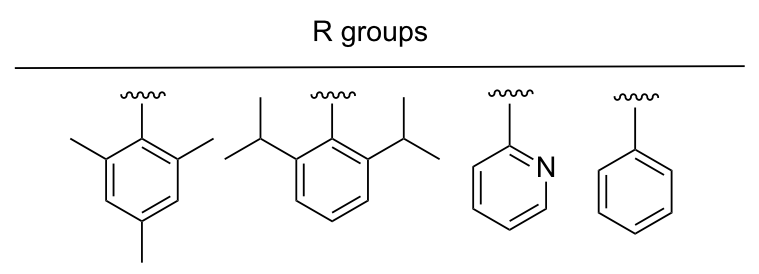


Table 1: Comparison of various preparations of the benzannulated $\mathrm{NHCs}$ : $1-\mathrm{Cl}, 2-\mathrm{Cl}, 3-\mathrm{Cl}$ and $4-\mathrm{Cl}$, and of $1-\mathrm{BF}_{4}, 3-\mathrm{BF}_{4}$ and $4-\mathrm{BF}_{4}$.

A

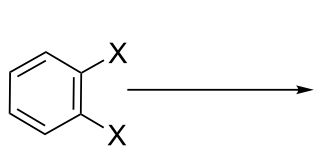<smiles>[R]N1C=C([Cl+])N([R])c2ccccc21</smiles>

$\mathrm{X}=\mathrm{Br}, \mathrm{Cl}, \mathrm{NH}_{2}$

$\mathrm{R}=\mathrm{Ph}, \mathrm{Py}$, Mes, $(2,6-\mathrm{iPr}) \mathrm{C}_{6} \mathrm{H}_{4}$

\begin{tabular}{cccccccc}
\hline $\begin{array}{c}\text { Starting } \\
\text { materials }\end{array}$ & $\begin{array}{c}\text { Reaction } \\
\text { conditions }\end{array}$ & $\begin{array}{c}\text { Intermediate product } \\
(\mathbf{A})\end{array}$ & $\begin{array}{c}\text { Reaction } \\
\text { conditions }\end{array}$ & $\begin{array}{c}\text { Final } \\
\text { product } \\
(\mathbf{B})\end{array}$ & $\begin{array}{c}\text { Time } \\
(\mathrm{h})^{\mathrm{a}}\end{array}$ & $\begin{array}{c}\text { Steps } \\
\mathrm{b}\end{array}$ & $\begin{array}{c}\text { Overall } \\
\text { yield } \\
(\%)\end{array}$ \\
\hline
\end{tabular}<smiles>Clc1ccccc1Cl</smiles>

$115^{\circ} \mathrm{C}, 15 \mathrm{~h}$, $\mathrm{Pd}(\mathrm{dba})_{2}$, $\mathrm{P}(\mathrm{t}-\mathrm{Bu})_{3}$, $t$-BuONa, toluene yield $82 \%$<smiles>Cc1cc(C)c(Nc2ccccc2Nc2c(C)cc(C)cc2C)c(C)c1</smiles>

$145^{\circ} \mathrm{C}$ $1,25 \mathrm{~h}$, $\mathrm{HC}(\mathrm{OEt})_{3}$, neat, TMSCl yield $67 \%$

6

$115^{\circ} \mathrm{C}, 15 \mathrm{~h}$, $\mathrm{Pd}(\mathrm{dba})_{2}$, $\mathrm{P}(t-\mathrm{Bu})_{3}$, $t$-BuONa, toluene yield $58 \%$<smiles>CC(C)c1cccc(C(C)C)c1N</smiles><smiles>Clc1ccccc1Cl</smiles><smiles>Nc1ccccc1</smiles>
$92{ }^{\circ} \mathrm{C}, 4 \mathrm{~h}$, $\mathrm{Pd}(\mathrm{dba})_{2}$, $\mathrm{P}(t-\mathrm{Bu})_{3}$, toluene yield $89 \%$<smiles>[3H]c1ccc(Nc2c(C(C)C)cccc2C(C)C)c(Nc2c(C(C)C)cccc2C(C)CC)c1</smiles>

$145^{\circ} \mathrm{C}$ $3.3 \mathrm{~h}$, $\mathrm{HC}(\mathrm{OEt})_{3}$ neat, TMSCl yield $28 \%$<smiles>c1ccc(Nc2ccccc2Nc2ccccc2)cc1</smiles>

$145^{\circ} \mathrm{C}, 1 \mathrm{~h}$, $\mathrm{HC}(\mathrm{OEt})_{3}$, neat, TMSCl Yield 83\% 5<smiles>c1ccc(Nc2cc[13c]cc2Nc2ccccn2)nc1</smiles>
Microwave $185^{\circ} \mathrm{C}$, $0.58 \mathrm{~h}$, neat,<smiles>Clc1ccccn1</smiles>
yield $91 \%$<smiles>Cc1cc(C)c(-n2c(=O)n(-c3c(C)cc(C)cc3C)c3ccccc32)c(C)c1</smiles>

1-Cl<smiles>CC(C)c1cccc(C(C)C)c1-n1c(=O)n(-c2c(C(C)C)cccc2C(C)C)c2c(C(C)C)cccc21</smiles>

\section{2}

16

This

2-Cl<smiles>[O-]c1cn(-c2ccccc2)c2ccccc12</smiles>

5 2 74

This

3-Cl<smiles></smiles>

1.75
This work $^{\mathrm{C}}$ 
Table 1: Comparison of various preparations of the benzannulated $\mathrm{NHCs}$ : $1-\mathrm{Cl}, \mathbf{2}-\mathrm{Cl}, 3-\mathrm{Cl}$ and $4-\mathrm{Cl}$, and of 1-BF 4 , 3-BF 4 and 4-BF 4 .<smiles>Nc1ccccc1N</smiles>

$80^{\circ} \mathrm{C}, 18 \mathrm{~h}$ DMSO, Cul, L-Pro, $\mathrm{K}_{2} \mathrm{CO}_{3}$ yield $30 \%$<smiles>c1ccc(Nc2ccccc2Nc2ccccc2)cc1</smiles>

5<smiles>Nc1ccccc1N</smiles>
$10^{\circ} \mathrm{C}, 15 \mathrm{~h}$, $\mathrm{Pd}_{2}(\mathrm{dba})_{3}$ BINAP, $\mathrm{NaOt}-\mathrm{Bu}$, toluene yield $86 \%$

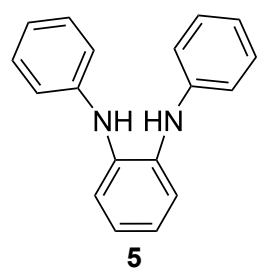

$80^{\circ} \mathrm{C}, 2 \mathrm{~h}$, $\mathrm{HC}(\mathrm{OEt})_{3}$ $\mathrm{HCl}$ conc. $\mathrm{HCOOH}$ cat. yield $90 \%$ $\mathrm{HC}(\mathrm{OEt})_{3}$ $\mathrm{HCl}$ conc., $\mathrm{HCOOH}$ cat. yield $91 \%$<smiles>[O-]c1cn(-c2ccccc2)c2ccccc12</smiles>
20 2 27 [44]<smiles>Brc1ccccc1</smiles>
yield $86 \%$<smiles>Nc1ccccc1N</smiles>

$110^{\circ} \mathrm{C}, 15 \mathrm{~h}$, $\mathrm{Pd}_{2}(\mathrm{dba})_{3}$ BINAP, $\mathrm{NaOt}$-Bu,<smiles>Brc1ccccn1</smiles>
toluene yield $91 \%$

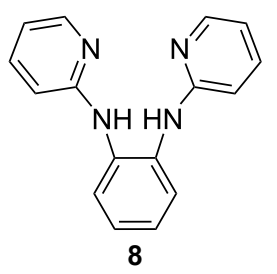

$80^{\circ} \mathrm{C}, 2 \mathrm{~h}$, $\mathrm{HC}(\mathrm{OEt})_{3}$, $\mathrm{HCl}$ conc. $\mathrm{HCOOH}$ cat. yield $94 \%$<smiles>[O-]c1cn(-c2ccccc2)c2ccccc12</smiles>

17 2 77 [45]

3-Cl<smiles>Brc1ccccc1Br</smiles>

$110^{\circ} \mathrm{C}, 14 \mathrm{~h}$, $\mathrm{Pd}(\mathrm{OAc})_{2}$, BINAP, $\mathrm{NaOt}-\mathrm{Bu}$, toluene yield $86 \%$<smiles>Cc1cc(C)c(Nc2ccccc2Nc2c(C)cc(C)cc2C)c(C)c1</smiles>
three
steps ${ }^{d}$
total time
$97 \mathrm{~h}$
overall
yield $29 \%$<smiles>Cc1cc(C)c(-n2c(=[Pt])n(-c3c(C)cc(C)cc3C)c3ccccc32)c(C)c1</smiles>

1-BF 4<smiles>Brc1ccccc1Br</smiles>

$60{ }^{\circ} \mathrm{C}, 15 \mathrm{~h}$, $\mathrm{Pd}(\mathrm{OAc})_{2}$, BINAP, $\mathrm{NaOt}-\mathrm{Bu}$, toluene yield $86 \%$ $-78^{\circ} \mathrm{C}$,
$\mathrm{THF}$, 12-crown-4, n-BuLi, TMSCl, $\mathrm{Cr}(\mathrm{CO})_{6}$ yield $13 \%$ 
<smiles>Nc1ccccc1N</smiles>

$110^{\circ} \mathrm{C}, 5 \mathrm{~h}$ $\mathrm{Pd}_{2}(\mathrm{dba})_{3}$, Xantphos, $\mathrm{NaOt}-\mathrm{Bu}$,<smiles>Brc1ccccc1</smiles>
toluene yield $91 \%$

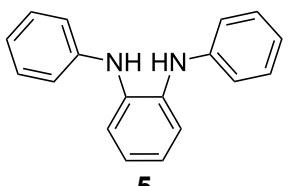

5

$145^{\circ} \mathrm{C}$, $18 \mathrm{~h}$, neat $\mathrm{NH}_{4} \mathrm{BF}_{4}$, $\mathrm{HC}(\mathrm{OEt})_{3}$ yield $91 \%$<smiles>Nc1ccccc1N</smiles>
microwave, $185^{\circ} \mathrm{C}$, $0.58 \mathrm{~h}$, neat, yield $91 \%$

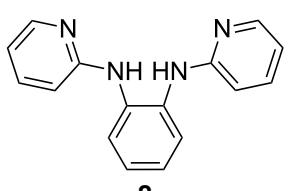

microwave,

$160^{\circ} \mathrm{C}$,

$0.75 \mathrm{~h}$,

neat,

$\mathrm{NH}_{4} \mathrm{BF}_{4}$,

$\mathrm{HC}(\mathrm{OEt})_{3}$

yield $99 \%$<smiles>Oc1cn(-c2ccccc2)c2ccccc12</smiles>

23

2

82

3-BF 4<smiles>[O-]c1cn(-c2ccccn2)c2ccccc12</smiles>

4-BF 4

${ }^{\text {aT}}$ Total reaction time: The overall reaction times refer to reaction times and do not take into account the work-up times needed in order to obtain either the intermediate and final products. ${ }^{b}$ Total number of steps: Steps with isolated intermediate or final products. ${ }^{\mathrm{c}} \mathrm{Compound} \mathbf{8}$, precursor to 4 -Cl or 4- $-\mathrm{BF}_{4}$, was prepared according to Ref. [47]. ${ }_{1}$ st step: $\mathrm{NalO}_{4}, \mathrm{SiO}_{2}, \mathrm{CH}_{2} \mathrm{Cl}_{2} / \mathrm{H}_{2} \mathrm{O}, 24 \mathrm{~h}$, room temperature, Yield $90 \%$; $2^{\text {nd }}$ step: a) $\mathrm{PivOCH} \mathrm{Cl}_{2} \mathrm{Cl}, \mathrm{AgOTf}$, $\mathrm{KOAc}, \mathrm{CH}_{2} \mathrm{Cl}_{2}, 48 \mathrm{~h}, 50^{\circ} \mathrm{C}$. b) PivOCH $\mathrm{Cl}_{2} \mathrm{AgOTf}, 24 \mathrm{~h}, 50^{\circ} \mathrm{C}$ (further 0.5 equiv of the pivalate/silver salt solution); $3^{\text {rd }}$ step: $\mathrm{HBF}_{4}, \mathrm{H}_{2} \mathrm{O}, 1 \mathrm{~h}$, room temperature, yield $32 \%$ (over two steps). ${ }^{e}$ The intermediate 6 reacts with a carbamoyl chromate intermediate to give rise directly to the organometallic complex (1,3-bis(2', 4',6'-trimethylphenyl)benzimidazol-2-ylidene)pentacarbonyl chromium(0).

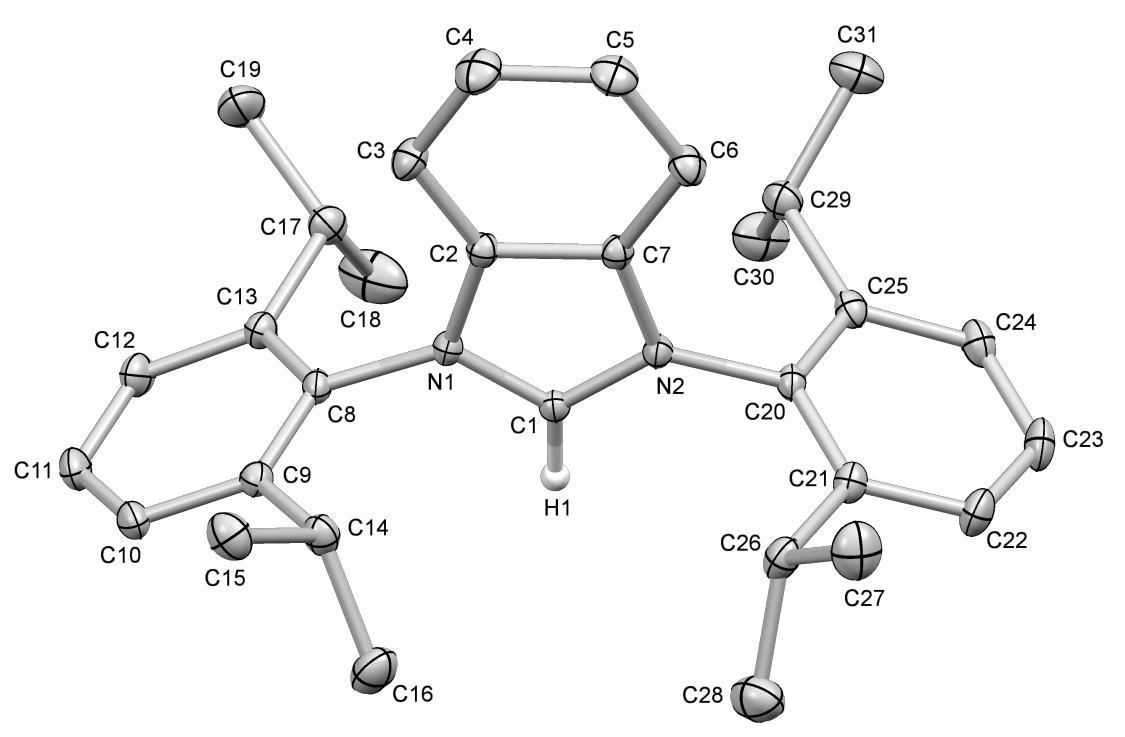

Figure 3: Molecular structure of 2-Cl. The solvate molecule, the counterion and the hydrogen atoms are omitted for clarity. The displacement ellipsoids are drawn at the $30 \%$ probability. Selected bond lengths $(\AA)$ and angles $\left(^{\circ}\right)$ : N2-C1-N1 109.3(2), N2-C1-H1 126.1(17), N1-C1-H1 124.6(17), N1-C1 1.334(3), N2-C1 1.330(3), N1-C2 1.392(3), N2-C7 1.397(3), N1-C8 1.448(3), N2-C20 1.447(3), C1-H1 0.97(3).

available for 3-Cl and 4-Cl, Table 1 suggests that the introduction of the TMSCl-triethyl orthoformate reagent has advantages in terms of overall yields and reaction times. The overall achieved yield of $16 \%$ for $2-\mathrm{Cl}$ is indeed low, but the short overall reaction time (19 hours) and the low number of steps (2) together with the fact that this is the only way to access this compound, makes the given route an acceptable synthetic pathway. 


\section{Conclusion}

We presented a new synthetic route for the synthesis of benzannulated imidazolium salts bearing bulky aromatic $\mathrm{N}$-substituents. The synthetic approach applied allowed to prepare the as yet inaccessible 1,3-diisopropylphenylbenzimidazolium chloride 2- $\mathrm{Cl}$ in two steps starting from 1,2-halo-substituted benzenes avoiding purification by column chromatography. In addition the known 1,3-dimesitylbenzimidazolium chloride 1-Cl could be synthesized in better yields and much shorter reaction times when compared with the previously reported method. The known benzannulated NHCs 1,3diphenylbenzimidazolium chloride 3-Cl and the 1,3-di(pyridin2-yl)benzimidazolium chloride 4-Cl could be prepared also in excellent overall yields and reduced reaction times, if compared with the synthetic access by previous methods. The synthetic access presented in this paper possesses various advantages over the conventional methodologies for the synthesis of benzimidazolium salts with bulky $\mathrm{N}$-substituents. The developed synthetic route may show greater generality and therefore constitutes a valid alternative to the earlier synthetic accesses.

\section{Experimental X-ray diffraction study}

Crystallographic data for the structure of 2-C1 has been deposited with the Cambridge Crystallographic Data Centre as supplementary publication number CCDC 1018301. Copies of the data can be obtained free of charge, on application to CCDC, 12 Union Road, Cambridge CB2 1EZ, UK (e-mail: deposit@ccdc.cam.ac.uk).

2-Cl: Crystal data for $\mathrm{C}_{32} \mathrm{H}_{41} \mathrm{~N}_{2} \mathrm{Cl}_{3}(M=560.02 \mathrm{~g} / \mathrm{mol})$ : monoclinic, space group $P 21 /$ n (no. 14), $a=12.6905(3) \AA, b=$ 18.5911(3) $\AA, c=14.3067(4) \AA, \beta=113.687(3)^{\circ}, V=$ 3091.02(15) $\AA^{3}, Z=4, T=183(2) \mathrm{K}, \mu\left(\mathrm{Cu} \mathrm{K}_{\alpha}\right)=2.843 \mathrm{~mm}^{-1}$, $D_{\text {calc }}=1.203 \mathrm{~g} / \mathrm{cm}^{3}, 40306$ reflections measured $\left(9.5^{\circ} \leq 2 \Theta \leq\right.$ $\left.178.9^{\circ}\right), 7060$ unique $\left(R_{\text {int }}=0.0323, R_{\text {sigma }}=0.0199\right)$ which were used in all calculations. The final $R_{1}$ was 0.0777 (I $>$ $2 \sigma(\mathrm{I}))$ and $w R_{2}$ was 0.2142 (all data).

\section{General procedures}

All manipulations were carried out under an atmosphere of dry nitrogen using standard Schlenk techniques or in a glove box (M. Braun 150B-G-II) filled with dry nitrogen. Solvents were freshly distilled under $\mathrm{N}_{2}$ by employing standard procedures and were degassed by freeze-thaw cycles prior to use. All chemicals used were purchased from Sigma-Aldrich and used as received. The deuterated solvents were dried with sodium/ benzophenone and vacuum transferred for storage in Schlenk flasks fitted with Teflon valves. ${ }^{1} \mathrm{H}$ NMR, ${ }^{13} \mathrm{C}\left\{{ }^{1} \mathrm{H}\right\}$ NMR data were recorded on a Varian Gemini-300, a Varian Mercury 200 or Bruker DRX 500 spectrometer using $5 \mathrm{~mm}$ diameter NMR tubes. Chemical shifts are expressed in parts per million (ppm). ${ }^{1} \mathrm{H}$ and ${ }^{13} \mathrm{C}\left\{{ }^{1} \mathrm{H}\right\}$ NMR spectra were referenced to the residual proton or ${ }^{13} \mathrm{C}$ resonances of the deuterated solvent. Signal patterns are reported as follows: s, singlet; d, doublet; dd, doublet of doublets; $t$, triplet; $m$, multiplet, q, quartet. ESIMS spectrometric data were obtained from an HCT Esquire Bruker Daltonics instrument, while the EIMS spectrometric data were obtained from a Varian 450GG-Saturn 2000 GC/MS/MS instrument using a Brechbühler column (30 m, ZB-5ms). The reactions that required the use of a microwave reactor were carried out using an Anton Paar Monowave 300. The high resolution ESI were performed by the Mass Service of the University of Zurich using a Bruker maXis apparatus. The compounds 5 [44], 6 [52], 7 [46], 8 [47,48] were prepared according to literature with small modifications.

Synthesis of 1,3-bis(2,4,6-trimethylphenyl)-1Hbenzo[d]imidazol-3-ium chloride (1-Cl). In a $125 \mathrm{~mL}$ two neck round-bottomed flask was weighed $N^{1}, N^{2}$-bis(2,4,6trimethylphenyl)-1,2-benzenediamine $(6,600 \mathrm{mg}, 1.74 \mathrm{mmol})$ and triethyl orthoformate $(60 \mathrm{~mL})$ was added and a fractional distillation apparatus equipped with a Vigreux column and a thermometer on the head of the latter was connected with the central neck of the flask. The green solution was stirred at $145^{\circ} \mathrm{C}$ until the color switched to orange $(15 \mathrm{~min})$ and then a small flux of nitrogen was passed through the solution until $30 \mathrm{~mL}$ of a mixture of $\mathrm{EtOH}$ and $\mathrm{HC}(\mathrm{OEt})_{3}$ distilled out ( 1 hour). Then the temperature was lowered to $90{ }^{\circ} \mathrm{C}$ and trimethylsilyl chloride (10 mL, $76.43 \mathrm{mmol})$ was added at once. A white-grey solid started to form after 10 minutes. Then the solution was cooled down to room temperature and the precipitate was filtered off and washed with $\mathrm{Et}_{2} \mathrm{O}(3 \times 15 \mathrm{~mL})$ then dried to afford in $455 \mathrm{mg}$ of 1-Cl as an off-white powder (1.16 mmol, $390.95 \mathrm{~g} / \mathrm{mol})$. Yield 67\%. ${ }^{1} \mathrm{H}$ NMR $\left(\mathrm{CD}_{3} \mathrm{OD}\right.$, $300 \mathrm{MHz}) \delta 10.09$ (s, 1H, N-CH1-N), $7.84(\mathrm{dd}, J=3.2 \mathrm{~Hz}, J=$ $6.3 \mathrm{~Hz}, 2 \mathrm{H}, \mathrm{H}-4, \mathrm{H}-5), 7.56(\mathrm{dd}, J=3.2 \mathrm{~Hz}, J=6.3 \mathrm{~Hz}, 2 \mathrm{H}$, H-3, H-6), 7.30 (s, 4H, H-10, H-12, H-16, H-18), 2.45 (s, 6H, p- $\mathrm{CH}_{3}$, mesityl), 2.11 (s, $12 \mathrm{H}, 0-\mathrm{CH}_{3}$, mesityl); ${ }^{13} \mathrm{C}\left\{{ }^{1} \mathrm{H}\right\}\left(\mathrm{CD}_{3} \mathrm{OD}, 75 \mathrm{MHz}\right) \delta 143.55(\mathrm{~N}-\mathrm{C} 1-\mathrm{N}), 136.54$ $(\mathrm{N}-\mathrm{C} 2=\mathrm{C} 7-\mathrm{N}), 132.94(\mathrm{C} 4=\mathrm{C} 5), 131.27(\mathrm{~N}-\mathrm{C} 8, \mathrm{C} 11), 130.24$ (C3, C6), 129.34 (C10, C12), 114.93 (C9, C13), 21.34 (p- $\left.\mathrm{CH}_{3}\right)$, $17.45\left(\mathrm{o}-\mathrm{CH}_{3}\right)$; HRMS-ESI (MeOH): calcd for $\mathrm{C}_{25} \mathrm{H}_{27} \mathrm{~N}_{2}{ }^{+}$, 355.21688; found, 355.21644 .

\section{Synthesis of 1,3-bis[2,6-bis(1-methylethyl)phenyl]-1H-} benzo[d] imidazol-3-ium chloride (2-Cl). In a $50 \mathrm{~mL}$ two neck round-bottomed flask was weighed $N^{1}, N^{2}$-bis[2,6-bis(1methylethyl)phenyl]-1,2-benzenediamine (7, $100 \mathrm{mg}$, $0.23 \mathrm{mmol})$ and triethyl orthoformate $(20 \mathrm{~mL})$ was added and a fractional distillation apparatus equipped with a Vigreux 
column and a thermometer on the head of the latter was connected with the central neck of the flask. The colourless suspension was stirred at $145{ }^{\circ} \mathrm{C}$ then after 20 minutes the colour switched to green. A small flux of nitrogen was passed through the solution until $15 \mathrm{~mL}$ of a mixture of EtOH and $\mathrm{HC}(\mathrm{OEt})_{3}$ distilled out (40 min). Then fresh triethyl orthoformate $(3 \mathrm{~mL})$ was added to the solution, followed by the trimethylsilyl chloride ( $4 \mathrm{~mL}, 31.51 \mathrm{mmol})$ added at once. The solution, that switched from dark green to dark red, was stirred at $50{ }^{\circ} \mathrm{C}$ for 3 hours, then the solvent was removed and the red solid was triturated with $\mathrm{Et}_{2} \mathrm{O}(20 \mathrm{~mL})$ and the precipitate was filtered off, washed with further $\mathrm{Et}_{2} \mathrm{O}(3 \times 10 \mathrm{~mL})$, then triturated with acetone $(3 \mathrm{~mL})$ and finally dried to afford $31 \mathrm{mg}$ of $2-\mathrm{Cl}$ as a grey powder $(0.065 \mathrm{mmol}, 475.11 \mathrm{~g} / \mathrm{mol})$. Yield 28\%. ${ }^{1} \mathrm{H}$ NMR $\left(\mathrm{CD}_{2} \mathrm{Cl}_{2}, 300 \mathrm{MHz}\right) \delta 12.95(\mathrm{~s}, 1 \mathrm{H}$, N-CH1-N), 7.74 (m, 6H, H-10, H-11, H12, H14, H-15, H-16), 7.52 (d, $J=7.8 \mathrm{~Hz}, 2 \mathrm{H}, \mathrm{H}-3, \mathrm{H}-6), 7.39$ (dd, $J=3.2 \mathrm{~Hz}, J=6.3$ $\mathrm{Hz}, 2 \mathrm{H}, \mathrm{H}-4, \mathrm{H}-5$ ), 2.29 (sept., $J=9 \mathrm{~Hz}, 4 \mathrm{H}, \mathrm{CH}_{3}-\mathrm{CH}-\mathrm{CH}_{3}$ isopropyl), 1.33 (d, $J=9 \mathrm{~Hz}, 12 \mathrm{H}, \mathrm{CH}_{3}$-isopropyl), 1.17 (d, $J=9$ $\mathrm{Hz}, 12 \mathrm{H}, \mathrm{CH}_{3}$-isopropyl); ${ }^{13} \mathrm{C} \mathrm{NMR}\left(\mathrm{CDCl}_{3}, 75 \mathrm{MHz}\right) \delta$ $146.80(\mathrm{~N}-\mathrm{C} 1-\mathrm{N}), 146.02(\mathrm{~N}-\mathrm{C} 8), 132.21(\mathrm{~N}-\mathrm{C} 2=\mathrm{C} 7-\mathrm{N})$, 128.5 (C9, C13, C15, C19), 127.45 (C10, C12, C16, C18), 124.97 (C11, C17), 113.42 (C4=C5), $29.42\left(\mathrm{CH}_{3}-\mathrm{CH}-\mathrm{CH}_{3}\right.$, isopropyl), $24.73\left(\mathrm{CH}_{3}\right.$, isopropyl), $23.10\left(\mathrm{CH}_{3}\right.$, isopropyl); HRMS-ESI (MeOH): calcd for $\mathrm{C}_{31} \mathrm{H}_{39} \mathrm{~N}_{2}{ }^{+}, 439.31078$; found, 439.31042 .

Synthesis of 1,3-diphenylbenzimidazolium chloride (3-CI). In a $50 \mathrm{~mL}$ two neck round-bottomed flask was weighed $N, N^{\prime}$ diphenylbenzene-1,2-diamine $(\mathbf{5}, 50 \mathrm{mg}, 0.19 \mathrm{mmol})$ and triethyl orthoformate $(15 \mathrm{~mL})$ was added and a fractional distillation apparatus equipped with a Vigreux column and a thermometer on the head of it, was connected with the central neck of the flask. The light blue suspension was stirred at $145{ }^{\circ} \mathrm{C}$ until the suspension became a light green solution (20 min), then a small flux of nitrogen was passed through the solution until $10 \mathrm{~mL}$ of a mixture of EtOH and $\mathrm{HC}(\mathrm{OEt})_{3}$ distilled out (ca. $45 \mathrm{~min}$ ). Then the trimethylsilyl chloride $(3.0 \mathrm{~mL}$, $23.64 \mathrm{mmol}$ ) was added at once and a light blue precipitate formed immediately. The solution was cooled down to room temperature and the precipitate was filtered off, washed with $\mathrm{Et}_{2} \mathrm{O}(3 \times 10 \mathrm{~mL})$ and then dried to afford $48 \mathrm{mg}$ of $3-\mathrm{Cl}$ as a slightly green powder $(0.157 \mathrm{mmol}, 306.79 \mathrm{~g} / \mathrm{mol})$. Yield $83 \%$. ${ }^{1} \mathrm{H}$ NMR $\left(\mathrm{CDCl}_{3}, 500 \mathrm{MHz}\right) \delta 11.51$ (s, 1H, N-C1H1-N,), 8.19 (d, $J=8 \mathrm{~Hz}, 4 \mathrm{H}, \mathrm{H} 9, \mathrm{H} 13, \mathrm{H} 15, \mathrm{H} 19), 7.79$ (dd, $J=3.5 \mathrm{~Hz}, J$ $=6.3 \mathrm{~Hz}, 2 \mathrm{H}, \mathrm{H} 4, \mathrm{H} 5), 7.68(\mathrm{~m}, 6 \mathrm{H}, \mathrm{H} 10, \mathrm{H} 11, \mathrm{H} 12, \mathrm{H} 16$, $\mathrm{H} 17, \mathrm{H} 18), 7.61$ (t, $J=7.4 \mathrm{~Hz}, 2 \mathrm{H}, \mathrm{H} 3, \mathrm{H} 6) ;{ }^{13} \mathrm{C}\left\{{ }^{1} \mathrm{H}\right\}\left(\mathrm{CDCl}_{3}\right.$, $125 \mathrm{MHz}) \delta 139.90(\mathrm{~N}-\mathrm{C} 1-\mathrm{N}), 130.68(\mathrm{~N}-\mathrm{C} 2=C 7-N), 129.39$ (C8), 128.80 (C4=C5), 128.53 (C3), 126.08 (C10), 123.32 (C11), 111.96 (C9); HRMS-ESI $\left(\mathrm{MeOH} / \mathrm{H}_{2} \mathrm{O} 1: 1\right)$ : calcd for $\mathrm{C}_{19} \mathrm{H}_{15} \mathrm{~N}_{2}$, 271.12297; found, 271.12281.

\section{Synthesis of 1,3-di(pyridin-2-yl)-1 $H$-benzo $[\boldsymbol{d}]$ imidazol-3-ium} chloride (4-CI). In a $125 \mathrm{~mL}$ two neck round-bottomed flask was weighed $N^{1}, N^{2}$-di(pyridin-2-yl)benzene-1,2-diamine (8, $300 \mathrm{mg}, 1.14 \mathrm{mmol})$ and triethyl orthoformate $(30 \mathrm{~mL})$ was added and a fractional distillation apparatus equipped with a Vigreux column and a thermometer on the head of the latter was connected with the central neck of the flask. The pink suspension was stirred at $145^{\circ} \mathrm{C}$ until the suspension became a red solution (10 $\mathrm{min})$, then a small flux of nitrogen was passed through the solution until $20 \mathrm{~mL}$ of a mixture of $\mathrm{EtOH}$ and $\mathrm{HC}(\mathrm{OEt})_{3}$ distilled out $(50 \mathrm{~min})$. Then trimethylsilyl chloride $(6 \mathrm{~mL}, 47.27 \mathrm{mmol})$ was added at once and the solution switched from deep red to blue and a blue precipitate formed immediately. The solution was cooled down to room temperature and the precipitate was filtered off, washed with $\mathrm{Et}_{2} \mathrm{O}(3 \times 10 \mathrm{~mL})$ and then dried to afford $344 \mathrm{mg}$ of $4-\mathrm{Cl}$ as a blue powder (1.12 mmol, $308.76 \mathrm{~g} / \mathrm{mol})$. Yield 98\%. ${ }^{1} \mathrm{H}$ NMR $\left(\mathrm{CD}_{3} \mathrm{CN}, 300 \mathrm{MHz}\right) \delta 10.07(\mathrm{~s}, \mathrm{~N}-\mathrm{C} 1 \mathrm{H} 1-\mathrm{N}, 1 \mathrm{H}), 8.84(\mathrm{dd}, J=$ $1.8 \mathrm{~Hz}, J=4.8 \mathrm{~Hz}, 2 \mathrm{H}, \mathrm{H}-12, \mathrm{H}-16), 8.48(\mathrm{dd}, J=3.2 \mathrm{~Hz}, J=$ $6.4 \mathrm{~Hz}, 2 \mathrm{H}, \mathrm{H}-4, \mathrm{H}-5), 8.28(\mathrm{td}, J=1.8 \mathrm{~Hz}, J=8.1 \mathrm{~Hz}, 2 \mathrm{H}$, $\mathrm{H}-10, \mathrm{H}-14), 8.03$ (dd, $J=1.8 \mathrm{~Hz}, J=8.1 \mathrm{~Hz}, 2 \mathrm{H}, \mathrm{H}-9, \mathrm{H}-13$ ), $7.89(\mathrm{dd}, J=3.2 \mathrm{~Hz}, J=6.4 \mathrm{~Hz}, 2 \mathrm{H}, \mathrm{H}-3, \mathrm{H}-6), 7.77$ (td, $J=$ $3.9 \mathrm{~Hz}, J=8.1 \mathrm{~Hz}, 2 \mathrm{H}, \mathrm{H}-11, \mathrm{H}-15) ;{ }^{13} \mathrm{C}\left\{{ }^{1} \mathrm{H}\right\}\left(\mathrm{CDCl}_{3}\right.$, $75 \mathrm{MHz}) \delta 150.0(\mathrm{~s}, \mathrm{~N}-\mathrm{C} 1-\mathrm{N}), 147.52$ (C8, C13), 140.73 (C10, $\mathrm{C} 12), 130.96(\mathrm{~N}-\mathrm{C} 2=\mathrm{C} 7-\mathrm{N}), 128.52(\mathrm{C} 4=\mathrm{C} 5), 125.89$ (C3, C6), 117.81 (C11, C16), 116.10 (C9, C14); HRMS-ESI ( $\mathrm{MeOH} / \mathrm{H}_{2} \mathrm{O} 1: 1$ ): calcd for $\mathrm{C}_{17} \mathrm{H}_{13} \mathrm{~N}_{4}, 273.11347$; found, 273.11308 .

Synthesis of $N^{\mathbf{1}}, N^{\mathbf{2}}$-diphenylbenzene-1,2-diamine (5). In a glove-box a $250 \mathrm{~mL}$ Schlenk flask was charged with $\mathrm{Pd}(\mathrm{dba})_{2}$ $(298 \mathrm{mg}, 0.52 \mathrm{mmol})$ and $\mathrm{P}(t-\mathrm{Bu})_{3}(100 \mathrm{mg}, 1.04 \mathrm{mmol})$. Subsequently was added toluene $(10 \mathrm{~mL})$ and the solution was stirred for $10 \mathrm{~min}$ at room temperature. Then 1,2-dichlorobenzene $(0.65 \mathrm{~mL}, 6.67 \mathrm{mmol})$ was added followed by aniline addition $(1.61 \mathrm{~mL}, 17.32 \mathrm{mmol})$ and the $t$-BuONa reagent (1664 mg, $17.32 \mathrm{mmol}$ ). An additional amount of toluene $(40 \mathrm{~mL})$ was used to rinse the walls of the Schlenk vessel and the solution was then heated at $92{ }^{\circ} \mathrm{C}$. The reaction was monitored by $\mathrm{GC}-\mathrm{MS}$ and after completion $(4 \mathrm{~h})$ to the solution were added AcOEt $(100 \mathrm{~mL})$ and water $(100 \mathrm{~mL})$. The organic layer was washed with brine and afterwards dried over $\mathrm{MgSO}_{4}$ and filtered. After the evaporation of the solvent under reduced pressure we obtained $1547 \mathrm{mg}$ of a deep blue solid (5.94 mmol, $\left.M_{\mathrm{w}}=260,33\right)$. The product has a sky-blue color when in solution, which is due to a small amount of impurities. The ${ }^{1} \mathrm{H}$ NMR analysis confirmed that $\mathbf{5}$ was pure enough to be used for the next synthetic step. Yield 89.1\%; GC-MS $\left(\mathrm{EI}^{+}\right)$: 11.074 $\min$ [260.3-261.2]; (98\%). ${ }^{1} \mathrm{H}$ NMR $\left(\mathrm{CDCl}_{3}, 300 \mathrm{MHz}\right) \delta 7.28$ $(\mathrm{m}, 6 \mathrm{H}), 6.97(\mathrm{~m}, 8 \mathrm{H}), 5.65(\mathrm{~s}, 2 \mathrm{H}, \mathrm{NH}) ;{ }^{13} \mathrm{C}\left\{{ }^{1} \mathrm{H}\right\} \mathrm{NMR}$ $\left(\mathrm{CDCl}_{3}, 75 \mathrm{MHz}\right) \delta 144.8(\mathrm{~s}, \mathrm{HN}-\mathrm{Cl}=\mathrm{C} 6-\mathrm{NH}), 135.0(\mathrm{~s}, \mathrm{C} 7)$, 
$129.3(\mathrm{~s}, \mathrm{C} 3=\mathrm{C} 4), 122.35(\mathrm{~s}, \mathrm{C} 2), 120.3(\mathrm{~s}, \mathrm{C} 9), 119.4(\mathrm{~s}, \mathrm{C} 10)$, $116.56(\mathrm{C} 8)$.

Synthesis of $N^{1}, N^{2}$-bis(2,4,6-trimethylphenyl)benzene-1,2diamine (6). Inside a glove box a $250 \mathrm{~mL}$ Schlenk flask was charged with $\mathrm{Pd}(\mathrm{dba})_{2}(23 \mathrm{mg}, 0.04 \mathrm{mmol})$, the $\mathrm{P}(t-\mathrm{Bu})_{3}$ $(9.0 \mathrm{mg}, 0.093 \mathrm{mmol})$ and subsequently toluene $(10 \mathrm{~mL})$. The solution was stirred for 10 minutes at room temperature. Then 1,2-dichlorobenzene $(0.322 \mathrm{~mL}, 3.33 \mathrm{mmol})$ was added followed by 2,4,6-trimethylaniline $(1.146 \mathrm{~mL}, 7.99 \mathrm{mmol})$ and $t$-BuONa (768 mg, $7.99 \mathrm{mmol}$ ) and an additional amount of toluene $(40 \mathrm{~mL})$ was used to rinse the walls of the Schlenk tube. The solution was then heated at $115{ }^{\circ} \mathrm{C}$ for 15 hours and the solid material that precipitated out of the solution was isolated by suction filtration. The so obtained cake was washed with water and ether and then dried to afford $941 \mathrm{mg}$ of 6 as a grayish powder $(2.73 \mathrm{mmol}, 344.49 \mathrm{~g} / \mathrm{mmol})$. Yield $82 \%$. The ${ }^{1} \mathrm{H}$ NMR analysis confirmed that 6 was pure enough to be used for the next step without further purification. MS-EI ${ }^{+}: 12.485$ $\min [344.5-345.3] ;{ }^{1} \mathrm{H} \mathrm{NMR}\left(\mathrm{CDCl}_{3}, 300 \mathrm{MHz}\right) \delta 7.025(\mathrm{~s}, 4 \mathrm{H}$, H-9, H-11, H-15, H-17), 6.72 (dt, $J=3.5 \mathrm{~Hz}, J=5.7 \mathrm{~Hz}, 2 \mathrm{H}$, H-4, H-5), 6.37 (dt, $J=3.5 \mathrm{~Hz}, J=5.7 \mathrm{~Hz}, 2 \mathrm{H}, \mathrm{H}-3, \mathrm{H}-6$ ), 5.169 (s broad, 2H, NH), $2.385\left(\mathrm{~s}, 6 \mathrm{H}, \mathrm{p}-\mathrm{CH}_{3}\right), 2.26(\mathrm{~s}, 12 \mathrm{H}$,

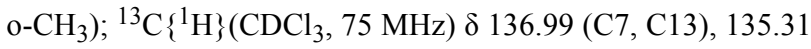
(C8, C12, C14, C18), 134.07 (C3, C6), 133.45 (C1, C2), 129.36 (C4, C5), 120.04 (C10, C16), 114.31 (C9, C11, C15, C17), $20.90\left(p-\mathrm{CH}_{3}\right), 18.18\left(o-\mathrm{CH}_{3}\right)$.

Synthesis of $N^{\mathbf{1}}, N^{\mathbf{2}}$-bis[2,6-bis(1-methylethyl)phenyl]benzene-1,2-diamine (7). Inside a glove box a $250 \mathrm{~mL}$ Schlenk flask was charged with $\mathrm{Pd}(\mathrm{dba})_{2}(98 \mathrm{mg}, 0.17 \mathrm{mmol}), \mathrm{P}(t-\mathrm{Bu})_{3}$ (33 mg, $0.374 \mathrm{mmol})$, then toluene $(20 \mathrm{~mL}$ ) was added, and the solution was stirred for 5 minutes at room temperature. Addition of 2,6-diisopropylaniline (7.84 mL, $37.4 \mathrm{mmol}), t$-BuONa (4127 mg, $40.8 \mathrm{mmol}$ ) and 1,2-dibromobenzene (4.184 mL, $34 \mathrm{mmol})$, was followed by additional toluene $(80 \mathrm{~mL})$. The solution was then heated at $115^{\circ} \mathrm{C}$ for 15 hours until a white solid separated from the solution and depositing on the walls of the Schlenk tube. The volume of toluene was reduced to one half and the suspension was filtered through a glass-frit and washed with water $(50 \mathrm{~mL})$ and with a mixture of water-methanol $(50 \mathrm{~mL}, 1: 2)$, then the solid was dried under vacuum to afford $8.45 \mathrm{~g}$ of 7 as a grey product $(19.72 \mathrm{mmol}$, $428.65 \mathrm{~g} / \mathrm{mol})$. The ${ }^{1} \mathrm{H}$ NMR analysis established that the product obtained was pure enough to be used for the next step. Yield 58\%. MS-EI ${ }^{+}: 9.97$ min [430-431]; ${ }^{1} \mathrm{H}$ NMR $\left(\mathrm{CD}_{2} \mathrm{Cl}_{2}\right.$, $300 \mathrm{MHz}) \delta 7.31$ (m, 6H, H-9, H-10, H-11), 6.66 (dd, $J=5.8$ $\mathrm{Hz}, J=3.5 \mathrm{~Hz}, 2 \mathrm{H}, \mathrm{H}-4, \mathrm{H}-5), 6.29$ (dd, $J=5.8 \mathrm{~Hz}, J=3.5 \mathrm{~Hz}$, 2H, H-3, H-6), 5.30 (s, 2H, NH), 3.24 (sept., $J=6.8 \mathrm{~Hz}, 4 \mathrm{H}$, $\mathrm{CH}_{3}-\mathrm{CH}-\mathrm{CH}_{3}$ isopropyl), 1.24 (d, $\mathrm{J}=6.8 \mathrm{~Hz}, 12 \mathrm{H}, \mathrm{CH}_{3}$-isopropyl), 1.18 (d, $J=6.8 \mathrm{~Hz}, 12 \mathrm{H}, \mathrm{CH}_{3}$-isopropyl); ${ }^{13} \mathrm{C}\left\{{ }^{1} \mathrm{H}\right\}$
$\left(\mathrm{CD}_{2} \mathrm{Cl}_{2}, 75 \mathrm{MHz}\right) \delta 145.77(\mathrm{HN}-\mathrm{C} 1=C 2-\mathrm{NH}), 137.25(\mathrm{NH}-$ C7), 137.12 (C8, C12), 126.49 (C10), 124.14 (C9, C11), 120.20 (C4,C5), 114.69 (C6), $28.61\left(\mathrm{CH}_{3}-\mathrm{CH}-\mathrm{CH}_{3}\right.$, isopropyl), 24.848 $\left(\mathrm{CH}_{3}\right.$, isopropyl), $23.29\left(\mathrm{CH}_{3}\right.$, isopropyl).

\section{Supporting Information}

\section{Supporting Information File 1}

CIF file of compound $\mathbf{5}$.

[http://www.beilstein-journals.org/bjoc/content/

supplementary/1860-5397-11-182-S1.cif]

\section{Supporting Information File 2}

NMR and HRMS-ESI analyses.

[http://www.beilstein-journals.org/bjoc/content/

supplementary/1860-5397-11-182-S2.pdf]

\section{Acknowledgements}

Funding from the Swiss National Science Foundation (SNSF) and the University of Zurich (UZH) is gratefully acknowledged.

\section{References}

1. Biju, A. T.; Hirano, K.; Fröhlich, R.; Glorius, F. Chem. - Asian J. 2009, 4, 1786-1789. doi:10.1002/asia.200900410

2. Visbal, R.; Concepción, M. Chem. Soc. Rev. 2014, 43, 3551-3574. doi:10.1039/c3cs60466g

3. Lazreg, F.; Cazin, C. S. J. Medical Applications of NHC-Gold and -Copper Complexes. In N-Heterocyclic Carbenes: Effective Tools for Organometallic Synthesis; Nolan, S. P., Ed.; Wiley-VCH: Weinheim, 2014. doi:10.1002/9783527671229.ch07

4. Schuster, O.; Mercs, L.; Albrecht, M. Chimia 2010, 64, 184-187. doi:10.2533/chimia.2010.184

5. Mercs, L.; Albrecht, M. Chem. Soc. Rev. 2010, 39, 1903-1912. doi:10.1039/b902238b

6. Hopkinson, M. N.; Richter, C.; Schedler, M.; Glorius, F. Nature 2014, 510, 485-496. doi:10.1038/nature13384

7. Herrmann, W. A. Angew. Chem., Int. Ed. 2002, 41, 1290-1309. doi:10.1002/1521-3773(20020415)41:8<1290::AID-ANIE1290>3.0.CO; 2-Y

8. Peris, E.; Crabtree, R. H. Coord. Chem. Rev. 2004, 248, 2239-2246. doi:10.1016/j.ccr.2004.04.014

9. Diez-González, S.; Marion, N.; Nolan, S. P. Chem. Rev. 2009, 109, 3612-3676. doi:10.1021/cr900074m

10. Fortman, G. C.; Nolan, S. P. Chem. Soc. Rev. 2011, 40, 5151-5169. doi:10.1039/c1cs15088j

11. Bugaut, X.; Glorius, F. Chem. Soc. Rev. 2012, 41, 3511-3522. doi:10.1039/c2cs15333e

12. Fèvre, M.; Pinaud, J.; Gnanou, Y.; Vignolle, J.; Taton, D. Chem. Soc. Rev. 2013, 42, 2142-2172. doi:10.1039/c2cs35383k

13. Biju, A. T.; Kuhl, N.; Glorius, F. Acc. Chem. Res. 2011, 44, 1182-1195. doi:10.1021/ar2000716

14. Marion, N.; Diez-González, S.; Nolan, S. P. Angew. Chem., Int. Ed. 2007, 46, 2988-3000. doi:10.1002/anie.200603380

15. Lamm, V.; Pan, X.; Taniguchi, T.; Curran, D. P. Beilstein J. Org. Chem. 2013, 9, 675-680. doi:10.3762/bjoc.9.76 
16. Chang, C.-F.; Cheng, Y.-M.; Chi, Y.; Chiu, Y.-C.; Lin, C.-C.; Lee, G.-H.; Chou, P.-T.; Chen, C.-C.; Chang, C.-H.; Wu, C.-C.

Angew. Chem., Int. Ed. 2008, 47, 4542-4545. doi:10.1002/anie.200800748

17. Sasabe, H.; Takamatsu, J.; Motoyama, T.; Watanabe, S.; Wagenblast, G.; Langer, N.; Molt, O.; Fuchs, E.; Lennartz, C.; Kido, J. Adv. Mater. 2010, 22, 5003-5007. doi:10.1002/adma.201002254

18. Hock, S. J.; Schaper, L.-A.; Herrmann, W. A.; Kühn, F. E. Chem. Soc. Rev. 2013, 42, 5073-5089. doi:10.1039/c3cs60019j

19. Fuchs, E.; Langer, N.; Molt, O.; Dormann, K.; Schildknecht, C.; Watanabe, S.; Wagenblast, G.; Lennartz, C.; Schäfer, T.; Wolleb, H.; Figueira, D. T. M.; Metz, S.; Metal, P. Metal complexes comprising diazabenzimidazol carbene-ligands and the use thereof in oleds. PCT Int. Appl. WO 2011073149 A1, June 23, 2011.

20. Arduengo, A. J., III; Harlow, R. L.; Kline, M. J. Am. Chem. Soc. 1991, 113, 361-363. doi:10.1021/ja00001a054

21. Hashmi, A. S. K.; Yu, Y.; Rominger, F. Organometallics 2012, 31 , 895-904. doi:10.1021/om2008919

22. Prasad, B. A. B.; Gilbertson, S. R. Org. Lett. 2009, 11, 3710-3713. doi:10.1021/ol901189m

23. Hintermann, L. Beilstein J. Org. Chem. 2007, 3, No. 22. doi:10.1186/1860-5397-3-22

24. Arduengo, A. J., III; Krafczyk, R.; Schmutzler, R.; Craig, H. A.; Goerlich, J. R.; Marshall, W. J.; Unverzagt, M. Tetrahedron 1999, 55, 14523-14534. doi:10.1016/S0040-4020(99)00927-8

25. Hirano, K.; Biju, A. T.; Glorius, F. J. Org. Chem. 2009, 74, 9570-9572. doi:10.1021/jo902160y

26. Izquierdo, J.; Orue, A.; Scheidt, K. A. J. Am. Chem. Soc. 2013, 135, 10634-10637. doi:10.1021/ja405833m

27. Chan, A.; Scheidt, K. A. J. Am. Chem. Soc. 2007, 129, 5334-5335. doi:10.1021/ja0709167

28. Huynh, H. V.; Wong, L. R.; Ng, P. S. Organometallics 2008, 27, 2231-2237. doi:10.1021/om800004j

29. Anantharaman, G.; Elango, K. Synth. React. Inorg., Met.-Org., Nano-Met. Chem. 2007, 37, 719-723.

30. Kishore, R.; Das, S. K. J. Mol. Struct. 2013, 1053, 38-47. doi:10.1016/j.molstruc.2013.08.051

31. Li, J. P.; Huang, Y.; Xie, M.-S.; Qu, G.-R.; Niu, H.-Y.; Wang, H.-X.; Qin, B.-W.; Guo, H.-M. J. Org. Chem. 2013, 78, 12629-12636. doi:10.1021/jo402248d

32. Lima, H. M.; Lovely, C. J. Org. Lett. 2011, 13, 5736-5739. doi:10.1021/ol2022438

33. Mayuka, H. Japanese Patent JP 2010278114 A, Sept 12, 2010.

34. Fang, W.; Jiang, J.; Xu, Y.; Zhou, J.; Tu, T. Tetrahedron 2013, 69 , 673-679. doi:10.1016/j.tet.2012.11.003

35. Gürbüz, N.; Yaşar, S.; Özcan, E. Ö.; Özdemir, I.; Çetinkaya, B. Eur. J. Inorg. Chem. 2010, 3051-3056. doi:10.1002/ejic.201000181

36. Türkmen, H.; Pape, T.; Hahn, F. E.; Çetinkaya, B. Eur. J. Inorg. Chem. 2009, 285-294. doi:10.1002/ejic.200800948

37. Page, P. C. B.; Buckley, B. R.; Christie, S. D. R.; Edgar, M.; Poulton, A. M.; Elsegood, M. R. J.; McKee, V. J. Organomet. Chem. 2005, 690, 6210-6216. doi:10.1016/j.jorganchem.2005.09.015

38. Chianese, A. R.; Mo, A.; Datta, D. Organometallics 2009, 28, 465-472. doi:10.1021/om800878m

39. Sanderson, M. D.; Kamplain, J. W.; Bielawski, C. W. J. Am. Chem. Soc. 2006, 128, 16514-16515. doi:10.1021/ja067475w

40. Pompeo, M.; Froese, R. D. J.; Hadei, N.; Organ, M. G. Angew. Chem., Int. Ed. 2012, 51, 11354-11357. doi:10.1002/anie.201205747
41. Tennyson, A. G.; Ono, R. J.; Hudnall, T. W.; Khramov, D. M.; Er, J. A. V.; Kamplain, J. W.; Lynch, V. M.; Sessler, J. L.; Bielawski, C. W. Chem. - Eur. J. 2010, 16, 304-315. doi:10.1002/chem.200901883

42. Borguet, Y.; Zaragoza, G.; Demonceau, A.; Delaude, L. Adv. Synth. Catal. 2012, 354, 1356-1362. doi:10.1002/adsc.201100890

43. Borguet, Y.; Zaragoza, G.; Demonceau, A.; Delaude, L. Dalton Trans. 2013, 42, 7287-7296. doi:10.1039/C2DT31520C

44. Huang, W.; Guo, J.; Xiao, Y.; Zhu, M.; Zou, G.; Tang, J. Tetrahedron 2005, 61, 9783-9790. doi:10.1016/j.tet.2005.06.060

45. Wang, H.; Xia, Y.; Lv, S.; Xu, J.; Sun, Z. Tetrahedron Lett. 2013, 54, 2124-2127. doi:10.1016/j.tetlet.2013.02.006

46. Wenderski, T.; Light, K. M.; Ogrin, D.; Bott, S. G.; Harlan, C. J. Tetrahedron Lett. 2004, 45, 6851-6853. doi:10.1016/j.tetlet.2004.07.116

47. Hao, X.; Yuan, J.; Yu, G.-A.; Qiu, M.-Q.; She, N.-F.; Sun, Y.; Zhao, C.; Mao, S.-L.; Yin, J.; Liu, S.-H. J. Org. Chem. 2012, 99-105. doi:10.1016/j.jorganchem.2012.02.007

48. Grieco, G.; Blacque, O.; Berke, H. Acta Crystallogr., Sect. E: Struct. Rep. Online 2011, 67, o2066-02067. doi:10.1107/S1600536811027942

49. Gdaniec, M.; Bensemann, I.; Polonski, T. Acta Crystallogr., Sect. C: Cryst. Struct. Commun. 2004, 60, o215-0216. doi:10.1107/S010827010400068X

50. Tomat, E.; Cuesta, L.; Lynch, V. M.; Sessler, J. L. Inorg. Chem. 2007, 46, 6224-6226. doi:10.1021/ic700933p

51. Stefankiewicz, A. R.; Wałesa-Chorab, M.; Harrowfield, J.; Kubicki, M.; Hnatejko, Z.; Korabik, M.; Patroniak, V. Dalton Trans. 2013, 42, 1743-1751. doi:10.1039/C2DT31982A

52. Pombeiro, A. J. L.; Hills, A.; Hughes, D. L.; Richards, R. L. J. Organomet. Chem. 1988, 352, C5-C7. doi:10.1016/0022-328X(88)83042-0

53. Sakurai, H.; Sugitani, K.; Moriuchi, T.; Hirao, T. J. Org. Chem. 2005, 690, 1750-1755. doi:10.1016/j.jorganchem.2005.01.030

54. Tronnier, A.; Pöthig, A.; Metz, S.; Wagenblast, G.; Münster, I.; Strassner, T. Inorg. Chem. 2014, 53, 6346-6356. doi:10.1021/ic500971z

55. Jacquemard, U.; Harpainter, P.; Roland, S. Tetrahedron Lett. 2013, 54, 4793-4795. doi:10.1016/j.tetlet.2013.06.132

\section{License and Terms}

This is an Open Access article under the terms of the Creative Commons Attribution License (http://creativecommons.org/licenses/by/2.0), which permits unrestricted use, distribution, and reproduction in any medium, provided the original work is properly cited.

The license is subject to the Beilstein Journal of Organic Chemistry terms and conditions: (http://www.beilstein-journals.org/bjoc)

The definitive version of this article is the electronic one which can be found at: doi:10.3762/bjoc. 11.182 